\title{
SOBRE A VIDA E A OBRA DE DUNS SCOTUS
}

\author{
Luis Alberto De Boni *
}

\begin{abstract}
RESUMO - A descoberta e publicação, durante o século $\mathrm{XX}$, de inúmeros documentos manuscritos referentes a Duns Scotus, bem como o desenvolvimento de novas técnicas de pesquisa e de edição crítica de textos, trouxeram novos conhecimentos sobre esse autor. Em contra-partida, desfizeram-se algumas lendas a respeito dele. 0 trabalho de edição de sua obra, embora ainda não concluído, permitiu determinar o que é propriamente de sua autoria, embora não se disponha de manuscritos provenientes diretamente dele.
\end{abstract}

PALAVRAS-CHAVE - História da Filosofia. Duns Scotus. Vida. Obras. Edição Crítica.

\begin{abstract}
The discovery and publication, throughout the XX century, of a number of manuscript documents referring to Duns Scotus, as well as the development of new techniques of research and critical edition of texts, have brought new knowledge about this author. Conversely, several legends regarding Scotus have been proved wrong. The edition of his oeuvres, though not concluded at this time, has allowed the determination of which works are indeed of his authorship, even though manuscripts originally written by Scotus are not available.

KEY WORDS - History of Philosophy. Duns Scotus. Life. Oeuvres. Critical Edition.
\end{abstract}

\section{A vida}

É lugar-comum dizer que o franciscano João Duns Scotus é, entre os grandes pensadores medievais, aquele a respeito do qual menos se conhece, e pode-se acrescentar que é também aquele cuja obra provoca os maiores debates. Se é verdade que, no decorrer do século XX, foram descobertos muitos documentos a seu respeito, não deixa também de ser verdade que, nesse mesmo período, maior ainda foi o que se desfez daquilo que se supunha saber sobre ele ${ }^{1}$.

As tentativas de reconstruir a vida de Scotus fundam-se em algumas poucas datas comprovadas, a partir das quais outras são propostas como prováveis. Tem-se, assim, o seguinte quadro, no qual as datas entre colchetes são conjeturas:

* Pontifícia Universidade Católica do Rio Grande do Sul.

1 Dentro da vasta bibliografia a respeito da vida e da obra de Scotus, duas obras são de fundamental importância: BALIĆ, C., 1965, que retoma tudo o que até então fora escrito sobre o tema, e VOS, A., 2006 (p. 13-147), que apresenta o atual Stand der Forschung e, com muita competência, aprofunda a análise de alguns pontos discutidos entre os especialistas.

\begin{tabular}{|l|l|l|l|l|l} 
VERITAS & Porto Alegre & v. 53 & n. 3 & jul./set. 2008 & p. 7-31
\end{tabular}


[1265-66] Nascimento em Duns, na Escócia.

Primeira alternativa

[1278-1283] Estudos, inclusive de filosofia, concluídos em Oxford.

[1284] Noviciado.

[1285-1288] Leitorado em Paris e talvez em

Cambridge.

[1288-1298] Estudo de teologia em Oxford.
Segunda alternativa

[1278] Estudos em Haddington.

[1280] Noviciado.

[1280/81-1287/88] Estudo de filosofia na Inglaterra.

[1291-1298] Estudos de teologia em Oxford ou, em parte, em Paris.

[1298] Encontra-se em Oxford.

1291 (17 de março) Ordenação sacerdotal em Northampton.

1300 ( 6 de julho) Apresentado ao bispo para ser autorizado a ouvir confissões.

Nesse mesmo ano:

- No Prólogo da Ordinatio, faz referência à derrota dos árabes ante os turcos.

- Disputa como bacharel na promoção de seu confrade Bridlington.

[1300/1301] Nomeado leitor em Paris pela Província da Inglaterra.

1302 Indicado, pelo Capítulo Geral, para estudos e promoção em Paris.

- Provavelmente assistente de Gonçalo de Espanha, na disputa deste com Mestre Eckhart, em Paris.

1303 (25 de junho) - Expulso da França por Filipe, o Belo, por se recusar a subscrever a lista dos que solicitavam a convocação de um concílio contra Bonifácio VIII.

1303 (dezembro) Oponente de Nicolau de Trivet, em uma disputa em Oxford.

1304 (abril) No Livro IV da Ordinatio, Scotus se refere a procedimentos ilegítimos do Papa Bento XI, a 31 de janeiro de 1304.

1304 [outubro] Respondente na inceptio de Egídio de Ligny, em Paris.

1304 (18 de novembro) Gonçalo de Espanha, Ministro-Geral da Ordem, seu antigo mestre, indica-o para o cargo de regente em Paris.

[1304(dezembro) ou 1305 (março/abril)] Inceptio, isto é, obtém o título de Mestre em Teologia.

1307 (25/26 de outubro) Alexandre de Alexandria é o regente em Paris.

1308 (20 de fevereiro) Já é leitor em Colônia.

1308 (8 de novembro) Morre em Colônia.

A primeira data documentalmente comprovada a respeito de Scotus é a de sua ordenação sacerdotal, em 17 de março de $1291^{2}$. A partir dela, é possível deduzir, aproximadamente, algumas outras datas anteriores. Scotus foi ordenado em Northampton, por Olivier Sutton, Bispo de Lincoln, diocese à qual Oxford pertencia. O mesmo bispo havia feito ordenações, em 23 de dezembro do ano anterior, em Wycombe. Segundo o costume da época, entre as Ordens Mendicantes, os candidatos recebiam o sacerdócio tão logo fosse possível. Se, pois, Duns Scotus se encontrava em Oxford, em dezembro de 1290, e não foi ordenado, deveu-se, com muita probabilidade, ao fato de que naquela data ele ainda não possuía os 25 anos de

2 Cf. LONGPRÉ, E., 1929 a, p. 54-62. Durante muito tempo, foram tomados como fonte fidedigna a respeito da vida de Duns Scotus, principalmente para os primeiros anos de vida, os célebres manuscritos de Brockie, hoje recusados pelo seu caráter de falsificação ou de fábula (cf. DOCHERTY, H., 1965 e 1966). 
idade requeridos pelo direito canônico. Tê-los-ia completado, portanto, entre 23 de dezembro e 17 de março do ano seguinte, o que significa dizer que o seu nascimento se deu entre o final de 1265 e os inícios de 1266.

O local de nascimento é o pequeno povoado de Duns, na Escócia, próximo à fronteira com a Inglaterra ${ }^{3}$. Os estudos iniciais aconteceram por volta de 1278, quando, portanto, Scotus tinha cerca de 12 anos, na localidade de Haddington, onde os frades possuíam uma escola. Seu tio, Frei Elias Duns, que ocupou cargos importantes na província escocesa, foi, provavelmente, quem o encaminhou para a vida religiosa.

A ida para Oxford, segundo alguns, foi devida aos estudos de filosofia, que teriam sido concluídos por volta de 1283. Estes estudos, bem como os de teologia realizaramse no Studium generale da Ordem, anexo à universidade. Em 1284, teria feito o noviciado, e a profissão religiosa em 1285. Segundo outros, por volta de 1280 deve ter feito o noviciado. Os estudos de filosofia, em grande parte, se não totalmente, em Oxford, teriam transcorrido entre os anos de 1280/1-1287/84.

Surge, nesse momento, nova cisão entre os pesquisadores: para uns, Scotus teria passado cerca de 4 anos em Paris, entre 1291 e 13005; outros julgam que ele esteve na França, durante o período de leitorado, cerca de 3 anos, logo após a conclusão dos estudos de filosofia; terceiros, enfim, são da opinião de que ele jamais esteve em Paris, antes de 1301-1302 6 .

Os dois primeiros grupos apresentam um argumento que parte da análise da estrutura interna da obra scotista e parece difícil de ser contradito. Observam eles que muitos dos autores com quem Scotus debate desde suas primeiras obras e que conhece muito bem eram mestres de Paris ${ }^{7}$. Isso se comprovou, como veremos, na edição crítica dos comentários ao De anima. Ninguém coloca em dúvida a formação filosófica oxfordiana de Scotus, e qualquer medievalista de conhecimentos médios percebe que as suas formas argumentativas são as de quem estudou em Oxford, e não em Paris. Contudo, também não se pode negar - e a edição crítica o mostra com clareza - que o frade escocês trava os seus principais debates teóricos com os mestres parisienses da geração que estava concluindo sua vida acadêmica em Paris, não

3 Cf. BALIĆ, C., 1965, p. 2-8. Houve quem defendesse que Scotus era irlandês, pois no passado scotus (escocês) era dito tanto dos escoceses como dos irlandeses, como se comprova no caso de João Scotus Eriúgena, que era irlandês. Porém, em contrário, foi demonstrado que, no século XIII, já se distinguia claramente entre scotus e hibernicus. Discutiu-se também a respeito do local de nascimento, mas hoje não há mais dúvidas a respeito. Alguns dos mais antigos manuscritos falam de Iohannes Duns. No século 18, ainda viviam em Duns famílias que se sabiam aparentadas com Scotus.

4 LONGPRÉ, E. (1929 c) e CALLEBAUT, A. (1931) propõem essas datas, que são aceitas no conjunto pelos demais. Sobre a questão das datas e locais da vida de Scotus, cf. o estudo atualizado de SHEPPARD, J. A., 2002 e VOS, A., 2006.

5 Cf. CALLEBAUT, A., 1924, p. 8; 1929, p. 355; BALIĆ, C., 1965, p. 10-11.

6 Cf. C. K. BRAMPTON, 1964; WOLTER, A. B., 1993, 1995, 1996 e VOS, A., 2004 e 2006.

7 Por brevidade, deixamos de elencar os muitos textos de especialistas, que observam como, inúmeras vezes, Scotus inicia a análise de um problema a partir do que foi dito a respeito por Henrique de Gand. Sugere-se mesmo, quando a leitura do texto scotista se apresenta muito difícil (o que não é raro), que, então, para compreendê-lo, se inicie pela passagem paralela do Gandavo. 
com os oxfordianos. Aliás, diga-se de passagem, a polêmica visão de Scotus, como sendo fundamentalmente um opositor de Tomás de Aquino, por cara que tenha sido às rixas entre as diversas escolas das Ordens religiosas, esboroou-se de todo com a edição crítica.

A hipótese mais antiga, defendida por A. Callebaut, E. Longpré, C. Balić e outros, afirma que Scotus esteve em Paris, para o estudo de teologia, por um determinado período (1293-1297, segundo C. Balić, baseado em A. Callebaut e A. G. Little; 1291-1298, conforme G. Gál). Com isso, teria cumprido os requisitos dessa Universidade, quanto ao número de anos de residência, a fim de poder posteriormente receber dela o título de mestre. Em favor desta proposta há um documento de Antônio André, secretário de Scotus, dizendo que este comentou a obra Isagoge de Porfírio, na qualidade de mestre ${ }^{8}$, o que significaria dizer: quando lecionava em Paris.

Diametralmente oposta a essa posição encontra-se, como vimos, aquela defendida por C. K. Brampton, A. B. Wolter e W. Courtenay. Atualmente, a maioria dos especialistas concorda com ela. Algumas datas a fundamentam. Assim, por exemplo, há o documento de 6 de julho de 1300, apresentado pelo provincial inglês ao bispo da diocese à qual Oxford pertencia, solicitando que 22 frades fossem autorizados a ouvir confissões; entre os candidatos, encontrava-se Duns Scotus ${ }^{9}$. Sabe-se, igualmente, que Scotus tomou parte, na qualidade de bacharel, na disputa dirigida por seu confrade F. Bridlington ${ }^{10}$, no ano acadêmico da regência deste, que seria o de 1300-1301. Isso significa que iniciou os seus estudos teológicos em 1288, tendo permanecido como ouvinte até 1293; como oponente, em 1294-1296; como respondente, em 1296-1297; dedicado à preparação da "leitura" do Livro das Sentenças, em 1297-1298; fazendo a leitura em 1298-1299, e comentando o texto bíblico em 1299-1300. Em 1301, os seus estudos estavam completos em Oxford, tornou-se baccalaureus formatus. Passou, então, mais um ano como leitor, em algum convento na Inglaterra (segundo C. K. Brampton), ou seguiu logo para a França (segundo W. Courtenay).

Em defesa dessa opinião aventa-se também um texto do Prólogo da Ordinatio. Ao tratar da permanência da Igreja, ele a contrasta com a fé judaica e, depois, refutando uma objeção a respeito da religião muçulmana, diz: "Se se objetar a respeito da permanência da seita de Maomé, respondo: ela iniciou mais de seiscentos anos depois da lei de Cristo e, em breve, se Deus quiser, haverá de se acabar, pois ficou muito debilitada no ano 1300 do calendário cristão, e muitos de seus sequazes foram mortos e muitos fugiram, e diz-se que existe, entre eles, uma profecia, segundo a

8 "Haec de dictis magistri fratris Ioannis Duns, natione Scoti, sedentis super cathedram magistralem, ut potui, colligens, in unum compilavi" ("Isto, na medida em que me foi possível, fui coligindo e compilei dos ditos do mestre frei João Duns, escocês de nacionalidade, quando ocupava a cátedra magistral"). Sobre este texto e a sua interpretação, cf. OPh I, St. Bonaventure: Franciscan Institute, I, p. XXIX-XXXII.

9 HECHICH, B., 1958, p. 21; LITTLE, A. G., 1943, p. 235.

10 Cf. LITTLE, A. G., 1932, p. 588; LONGPRÉ, E., 1929 c, p. 573. 
qual a seita deles vai se acabar"11. O autor se refere, aqui, à batalha de Medjemâa, de 23 dezembro de 1299, na qual os turcos, juntamente com os cristãos da Geórgia e da Armênia, derrotaram os árabes. A notícia deve ter chegado a Oxford no decorrer dos primeiros meses de 1300, e provocou grande euforia, que em breve haveria de arrefecer. Como esse texto não se encontra no local correspondente da Lectura, mas apenas na Ordinatio, está a indicar que Scotus, em 1300, já havia cumprido o seu dever de comentar o Livro das Sentenças e que se encontrava, então, preparando as correções para o texto definitivo. $O$ fato de, mais tarde, não haver suprimido esse parágrafo deve-se à brevidade da sua vida, que não lhe permitiu uma última revisão no texto.

Três outros documentos parecem-nos de suma importância, quer porque também eles comprovam que Scotus se encontrava em Oxford, por volta de 1300, quer porque, acima de tudo, estão a indicar que o jovem frade escocês, então com cerca de 34 anos, já possuía renome como teólogo. 0 primeiro deles é o de que, por essa época, Henrique de Harcley também comentou as Sentenças e, para tanto, valeu-se muito do recente comentário de $\mathrm{Scotus}^{12}$. O segundo documento é a obra do dominicano Tomás de Sutton, conhecido pelos medievais como Thomas Anglicus, mestre regente em Oxford, criticando acirradamente os ensinamentos de Scotus sobre a Trindade divina, no comentário ao Primeiro Livro das Sentenças ${ }^{13}$. Enfim, o terceiro documento é o comentário do franciscano Roberto de Cowton, que cita abundantemente o seu confrade ${ }^{14}$.

Em si, esses argumentos, dizendo que Scotus se encontrava em Oxford, por volta de 1300, não contradizem a opinião anterior, pois também os defensores desta admitem que, nessa época, Scotus estava de volta à Inglaterra. 0 peso desses argumentos encontra-se no fato de eles pressuporem que Scotus permaneceu durante todo o tempo de seus estudos teológicos em Oxford.

Um dos argumentos mais sólidos em defesa da estada de Scotus em Paris, durante a década de 1290, era o da legislação acadêmica que exigia um determinado número de anos de estudos na universidade local, como requisito para a obtenção da promoção. Fazendo um exame de toda essa legislação da época, W. Courtenay chegou às seguintes conclusões ${ }^{15}$ : boa parte das determinações surgiu no decorrer

11 "Si obiciatur de permanentia sectae Mahometi, respondeo: illa incepit plusquam sexcentis annis post legem Christi, et in brevi, Domino volente, finietur, quia multum debilitata est anno Christi millesimo trecentesimo, et eius cultores multi mortui, et plurimi sunt fugati; et prophetia dicitur apud eos esse quod secta eorum est finienda" (Ord. I, prol., n. 112; Vaticana I, 77).

12 Cf. a respeito Patres Editores (na época, principalmente BALIC, C.), Vaticana I, p. 95-121; id. "Adnotationes - De compendiis 'Ar. Cantr' et 'Arcl' respectu habito ad opera Henrici de Harcley" (Vaticana IV, p. 6*-46*).

13 Thomas Anglicus. Liber propugnatorius super librum primum sententiarum contra Joannem Scotum. A primeira edição impressa desta obra foi feita em Veneza, 1593 (reprint Frankfurt: Minerva, 1966). Os Padres Editores observam que tanto Tomás de Sutton como Roberto de Cowton, ao citarem Scotus, fazem-no pela Lectura (cf. Vaticana XVII, p. 13*-19*). No mesmo local, data-se a obra de R. Cowton entre 1309 e 1311, e a de T. Sutton como pouco posterior a 1311, sabendo-se, porém, que Sutton lecionou em Oxford tanto antes como depois de Scotus.

14 A obra desse autor não se encontra editada. Cf. Cod. Oxon. Merton 600.

15 COURTENAY, W., 1995, p. 154-158. 
do século XIV e, portanto, não existia por volta de 1300; diversas leis valiam para 0 clero secular, mas não para os religiosos, e, enfim, eram sempre possíveis - e muitas vezes previstas em lei - as exceções, como no caso da determinação do capítulo geral dos franciscanos, que exigia no mínimo quatro anos de estudos em Paris para a promoção, "a menos que, antes disso, [alguns frades] fossem considerados idôneos para exercer o ofício de doutor" ${ }^{16}$. Assim sendo, não seria por exigências de legislação acadêmica que Scotus seria obrigado a uma residência em Paris anterior a 1300.

Uma proposta mais recente é aquela defendida por M. B. Ingham, entre outros, baseando-se em estudos de W. Courtenay e de B. Roest ${ }^{17}$. Aceitando a proposta anterior e, por isso, reduzindo e antecipando os anos de estudo de filosofia, colocando o noviciado em 1284, e o início do estudo de teologia em 1288, há então um lapso de tempo de 3 anos, entre 1285 e 1288, durante o qual teria acontecido o "leitorado" um período destinado pelas Ordens Mendicantes dos agostinianos, carmelitas, dominicanos e franciscanos ao treinamento dos jovens frades, nas próprias casas da Ordem, para as finalidades do ensino e da pastoral. Tratava-se, pois, de uma atividade interna da Ordem, diferente daquele currículo previsto pela universidade, para os que desejavam obter titulação acadêmica. E como o convento de Paris era, de longe, o local mais renomado, cada província podia enviar alguns de seus melhores estudantes para o leitorado na capital francesa. É bem possível, pois, que Scotus tenha passado a maior parte desses anos em Paris. Em favor dessa hipótese encontram-se os estudos da edição sobre comentários sobre o De anima, aos quais a autora teve acesso na Catholic University of America. De fato, nessa obra, há pouco publicada, e situada pela equipe de pesquisadores entre 1286 e 1292, vê-se que 0 autor inspira-se principalmente nos mestres parisienses vivos ou desaparecidos há pouco tempo, como Tomás de Aquino, Henrique de Gand, Godofredo de Fontaines, Egídio Romano, bem como no franciscano Pedro de João Olivi e outros de seus confrades, entre os quais Gonçalo de Espanha ${ }^{18}$. Diversos desses professores devem ter tido, entre seus ouvintes, o jovem frade escocês.

Aqui surge uma outra questão: teria Scotus comentado as Sentenças também em Cambridge? Há diversos textos, já de início do século XIV, que se manifestam afirmativamente ${ }^{19}$. Após os estudos da Comissão Scotistica, houve uma tendência

16 "Illi autem qui mittuntur Parisius studeant quattuor annis ad minus, nisi adeo provecti fuerint, quod merito judicentur ydonei ad doctoris officium exercendum" (DENIFLE, H. e CHATELAIN, A., II, p. 57).

17 Cf. INGHAM, M. B., 2003, p. 15-16. A mesma influência Henrique de Gand exerceu nas questões sobre a Metafísica, obra iniciada nos primeiros tempos de vida acadêmica, mas na qual o autor trabalhou durante toda a vida (cf. G. A. Wilson, 1996, p. 107-124).

18 Cf. BAZAN, C., EMERY, K., GREEN, R., NOONE, TH., PLEVANO, R., TRAVER, A. Beati Joannis Duns Scoti: Quaestiones super secundum et tertium De anima (OPh V).Washington/St. Bonaventure: CUA/The Franciscan Institute, 2006, p. 121*-143*. Os editores, em trabalho magistral, resolveram, de uma vez por todas, a questão da autenticidade da obra, algo que, durante décadas fora questionado.

19 O mais conhecido desses documentos é, sem dúvida, o colofão do manuscrito 66 do Merton College, de início do século 14, que diz: "Haec de ordinatione ven. fratris J. Duns de Ordine Fratrum Minorum, qui floruit Cant., Oxon. Parisius et obiit in Colonia" ("Isto foi tomado da Ordinatio do venerável frei João Duns da Ordem dos Frades Menores, que floriu em Cambridge, Oxford, Paris e faleceu em Colônia"). Cf. CALLEBAUT, A., 1928c, p. 608; BALIĆ, C., 1965, p. 11. 
geral em considerar a Reportatio I-C como fruto das aulas que ele teria ministrado naquela localidade. Mas, não existe um documento sequer que diga em que data tal fato aconteceu. Para alguns, como M. B. Ingham, a Lectura de Cambridge teria sido a primeira de todas, tendo ocorrido entre os anos de 1285 e 1288, isto é, no período do leitorado. Segundo C. Balić, entre 1297 e 1300 Scotus teria comentado, em Cambridge, pela primeira vez, o Livro das Sentenças de Pedro Lombardo ${ }^{20}$. Para Brampton, há um ano da vida de Scotus, 1301, durante o qual poderia ter lecionado em Cambridge. Para outros, haveria a possibilidade de ele ter estado em Cambridge, quando de sua expulsão da França, em 1303. Assim pensa A. Vos, após minucioso estudo da questão ${ }^{21}$. Observa o autor que, na Inglaterra, só Oxford e Cambridge podiam conceder título em Teologia - e fora da Inglaterra, só Paris. Expulso da França, Scotus não podia lecionar em Oxford, cuja cátedra estava ocupada. Aconteceu, porém, que, em Cambridge, no ano acadêmico 1303-1304, veio a falecer Rogério Marston e os superiores teriam enviado Scotus para substituí-lo. Em favor de sua hipótese Vos arrola quatro argumentos: a) a passagem de Ord. I, d. 4, n.1, fruto da posterior revisão de Scotus, onde este diz expressamente que o tema a que se refere "encontra-se na questão cantabrigense" (Habetur in quaestione Cantabrigensi); b) também em revisão posterior da Ord. I, Scotus refere-se diversas vezes a Henrique de Harcley, padre secular que ele conheceu em Oxford. Harcley valeu-se muito das lições cantabringenses de Scotus, de quem foi dos primeiros admiradores, e este, ao examinar as posições de Harcley, remete também ao que ele próprio tratou em Cambridge; c) em Ord. II, d. 1, q. 2, n. 77, Scotus acrescenta, na revisão, o nome de Ricardo Sloley, um franciscano que estudou e lecionou em Cambridge. Foi nessa universidade que Scotus o deve ter conhecido; d) os editores da obra do doutor Sutil identificam as aulas de Cambridge com a Reportatio I-C, encontrada em Todi; acontece, porém, que, em Cambridge, os bacharéis não dispunham de secretário (socius) e, por isso, esse texto, mais do que uma reportatio, é uma lectura, um conjunto de notas do próprio autor na preparação da aula.

Em 1302, com certeza, Scotus se encontrava em Paris ${ }^{22}$. E vinha para comentar as Sentenças, isto é, para concluir os requisitos da promoção acadêmica em Paris, ele que, se tivesse ficado em Oxford, já seria mestre-regente. Como não se tem notícia de alguém que fosse a Paris para comentar essa obra, sem antes ter estado naquela universidade, confirma-se, assim, para alguns, que os seus anos de leitorado tenham mesmo transcorrido nessa cidade ${ }^{23}$. Caso contrário, argumentam, seria necessário

20 Para tanto, o autor faz uma minuciosa análise do início da d. 4 da Ordinatio (Vaticana IV, p. 1*-6*), a partir de um manuscrito da Lectura encontrado em Todi. Mas, há discordância quanto à interpretação de C. Balić (cf. RICHTER, W.,1988, p. 84-85).

21 VOS, A., 2006, p. 77-81.

22 A fonte em que vários autores se a beberam para fazer tal afirmação é a Chronica, p. 453.

23 "Here again, this move to Paris supports Courtenay's suggestion of the importance of the lectorate track and, additionally, supports the possibility that Scotus had already spent some time there. In fact, historians have no record of anyone chosen for the Parisian degree who had not already proved himself in the Parisian lectorate program. Ordinarily, a man who had been in the earlier program would have gone back to his province for teaching or administrative work before being chosen to return to the prestigious center of learning. It also explains how he might have been known to the Minister General" (INGHAM, M. B., 2003, p. 33). 
aceitar a hipótese de que ele esteve no grande centro universitário durante todo o (ou parte do) período que medeia entre 1291 e 1300. É bem provável que, no mesmo ano de 1302, tenha tomado parte, como bacharel, no debate entre seu mestre, Gonçalo de Espanha, e Mestre Eckhart ${ }^{24}$.

Mas, fatos extra-acadêmicos vieram atrapalhar-lhe o trabalho. Há anos as relações entre Filipe IV, o Belo, de França, e o Papa Bonifácio VIII estavam abaladas, devido à tentativa do rei em cobrar impostos do clero, a fim de financiar os seus projetos militares. Ora, Bonifácio fora eleito papa - por unanimidade dos cardeais em substituição a Celestino V, que havia renunciado. Em 1303, no auge da crise entre essas duas autoridades, os cardeais Colonna, inimigos do sumo pontífice, levantaram dúvidas sobre a validade da eleição de um papa, no caso de o pontífice anterior ainda estar vivo. Para a solução da querela, sugeriram a convocação de um concílio geral. Filipe, que conseguira erguer boa parte do clero francês contra as pretensões de Bonifácio, aderiu à idéia dos cardeais Colonna. Após manifestações públicas da universidade, de alguns bispos, de padres e frades, que arrastaram a multidão ante o palácio real, houve a visita de legados do rei aos conventos religiosos, devendo cada um dos frades manifestar se estava a favor ou contra a convocação do concílio. No convento dos franciscanos, 68 frades, quase todos franceses, declararamse a favor; na lista dos que se opunham, havia 87 nomes, dos quais o décimo era 0 de Fr. Joannes Scotus. No dia 25 de junho, um decreto real concedeu três dias para que os que se opunham à convocação do concílio se retirassem da França. Não existe documento dizendo para onde Scotus se dirigiu, mas tudo leva a crer que foi para Oxford, onde, em dezembro de 1303, teria exercido o ofício de oponente na disputa dirigida por Nicolau Trivet ${ }^{25}$. Em abril de 1304, nos Comentários ao Quarto Livro das Sentenças, ele alude a determinações ilegítimas do Papa Bento XI, tomadas em 31 de janeiro daquele ano, e também se refere à bula Inter cunctas, de 17 de abril26. Pelo modo de falar fica claro que ele ainda não voltara a Paris.

Mas, em breve, tudo se modificou. Bonifácio VIII morreu ainda em 1303. Em abril de 1304, Bento XI levantou os interditos de seu antecessor contra a Universidade de Paris e, pouco depois, Filipe, o Belo, permitiu o retorno dos estrangeiros. Pelo que se deduz de texto do próprio Scotus, em data próxima a outubro de 1304, ele devia estar em Paris, atuando como respondente nos debates de promoção de seu confrade, Egídio de Ligny ${ }^{27}$.

No dia 18 de novembro do mesmo ano de 1304, Gonçalo de Espanha, outrora mestre de Scotus, agora eleito Ministro-Geral da Ordem dos Frades Menores, enviava correspondência ao provincial da França. Tratava nela de quem deveria assumir a cátedra de professor, reservada aos franciscanos na grande universidade. O MinistroGeral apontava para seu antigo aluno, com palavras que poucas vezes um superior da Ordem empregou para louvar um seu jovem confrade. Dizia ele: "[...] Proponho à

24 KLIBANSKI, R., 1936, p. *XXX-*XXXIII; Cf. VOS, A., 2004, p. 11-13.

25 HECHICH, B., 1958, p. 21-22.

26 Cf. LITTLE, A. G., 1932, p. 577; BRAMPTON, C. K., 1964, p. 9-10.

27 Cf. CALLEBAUT, A., 1924, p. 209-213; LITTLE, A. G., 1932, p. 578-580. 
vossa indicação o padre João Scotus, dileto em Cristo, de cuja vida irrepreensível, a ciência excelente, a inteligência sutilíssima e outras insignes qualidades, estou perfeitamente informado, em parte por longa convivência, em parte pela fama divulgada por todo lugar [...]"28.

Em março/abril de 1305 - dezembro de 1304 também seria possível -, Scotus iniciou as suas atividades como regente da cátedra. Foi um período de muito trabalho. Para alguns, ele teria novamente ministrado curso sobre as Sentenças, mas não há unanimidade a respeito. Em 1305, participou de um debate com o dominicano Guilherme Pedro Godino, a respeito do princípio de individuação ${ }^{29}$. Além disso, na qualidade de regente - que equivaleria à de professor titular no nosso mundo acadêmico -, apresentou-se para as Questões quodlibetais, no advento de 1305 ou na quaresma de 1306, talvez compôs algumas Collationes, redigiu o De primo principio e continuou preparando o texto da Ordinatio. Foi também nessa época que tomou parte no debate a respeito da Imaculada Conceição de Maria.

Mas, tudo se acabou como por encanto. Por ordem do Ministro-Geral, cuja data precisa não se conhece - provavelmente junho de 1307 -, frei João foi transferido para o convento de Colônia. $O$ certo é que, em 25/26 de outubro deste ano, Alexandre de Alexandria era o regente em Paris, nomeado pelo capítulo geral dos franciscanos, realizado nesse ano em Tolosa ${ }^{30}$. Em documento da Província Renana, datado de 20 de fevereiro de 1308, o nome de Scotus é listado entre os de outros confrades de Colônia, que se manifestaram pela construção de um novo convento em Ruraemunda ${ }^{31}$.

O que levou o superior geral a remover Scotus de Paris para Colônia? Não há documentos a respeito. A resposta mais simples é a de que era costume, na Ordem, enviar os melhores frades a ministrar aulas pelas principais casas de formação. Com isso, resolvia-se também o problema de titulação dos muitos candidatos à espera da promoção, tanto em Paris, como em Oxford: o mestre actu regens permanecia um ano ou pouco mais no posto e era transferido, a fim de que outro pudesse obter 0 título de mestre. Poderia ser esse o motivo da transferência, mas há algumas sérias objeções a essa hipótese. Em primeiro lugar, o fato de que Scotus não era apenas mais um frade a ter alcançado a promoção. O Ministro-Geral que o transferiu foi aquele mesmo que, três anos antes, teceu-lhe o louvor e que sabia, sem dúvida, que o jovem frade escocês era o mais renomado mestre de Paris. Além disso, ele não

28 "Dilectum in Christo Patrem Joannem Scotum, de cujus vita laudabili, scientia excellenti, ingenioque subtilissimo, aliisque insignibus conditionibus suis, partim experientia longa, partim fama, quae ubique divulgata est, informatus sum ad plenum, dilectioni vestrae assigno [...]" (DENIFLE, H. e CHATELAIN, A., t. II, p. 117). - Pelo que conheço da história franciscana da Idade Média, elogio deste nível só o recebeu São Boaventura, quando o Ministro-Geral João de Parma, não desejando mais permanecer no cargo, foi solicitado a indicar o sucessor. 0 piedoso superior geral teria então dito mais ou menos o seguinte: "Gostaria de propor para o cargo a frei Boaventura, atualmente lecionando em Paris, uma pessoa em quem parece que não entrou o pecado original". E Boaventura, ausente, foi o escolhido pela unanimidade dos eleitores.

29 NOONE, T. B., 1995, p. 394-395.

30 LITTLE, A. G., 1932, p. 582; CALLEBAUT, A., 1928 a, p.235-236.

31 Cf. BALIĆ, C., 1965, p. 13, citando LAMPEN, W. 
estava sendo substituído por um novo bacharel, mas sim por Alexandre de Alexandria, um doctor bullatus, isto é, alguém que obtivera o título em Roma, por bula pontifícia. Essa nomeação, a nosso ver, está a indicar que o Ministro-Geral tinha outros problemas em vista, que não o da simples circulação de frades pelas diversas casas de formação da Ordem. E o motivo seria o processo que Filipe, o Belo, estava montando contra os templários, e que acabaria com a supressão da Ordem deles e a queima em fogueira pública de seu mestre, Jacques de Molay, em 1314. Já em 1305, valendo-se de denúncias secretas, Filipe iniciara o processo e, em 13 de outubro de 1307, cerca de 2.000 templários franceses foram presos e desapropriados de seus bens. Ora, Filipe foi um monarca que, para satisfazer as suas ambições e a sua fome de dinheiro, não desprezou nenhum meio e não sentiu o menor escrúpulo. Se teve a ousadia de mandar prender o Papa Bonifácio VIII, e disso jamais se arrependeu ${ }^{32}$, por que não ousaria tirar revanche de um frade escocês, que brilhava a poucas centenas de metros da corte, e que, há alguns anos, tivera a coragem de posicionarse contra o rei, em favor do papa? Era de temer que, quando o rei enviasse um documento sobre os templários aos dóceis professores da universidade - e isso aconteceu poucos anos mais tarde -, pedindo o apoio deles ao processo, novamente o Frater Joannes Scotus lhe viesse a contrariar os interesses. Nada melhor, pois, que tomar as devidas precauções. E para isso lá estava o professor Jean de Poully, do clero secular, que não apenas dava total aprovação aos atos reais, mas que também iniciava a sua campanha contra Scotus, a quem, mais tarde, haveria de acusar de herético ${ }^{33}$. Para Gonçalo de Espanha, nada mais aconselhável, pois, naquele momento, que a cautela. E a transferência para Colônia talvez levasse em conta também o fato de que, nesta cidade, se encontrava Mestre Eckhart, cujos ensinamentos, pensava-se, favoreciam os ideais de beguinos e beguinas.

Contudo, a estada de Scotus em Colônia foi mais curta do que se esperava. Calcula-se que deve ter chegado à cidade por volta de julho/agosto de 1307. E, em 8 de novembro de 1308, veio a falecer, parece que repentinamente. Contava 42 anos de idade.

Nos conventos franciscanos, naquela época, e em alguns até hoje, costumavase anotar o dia da morte de cada frade e, à noite, antes da janta, lia-se o Necrologium, isto é, o nome e um pequeno histórico dos frades falecidos naquele dia. Tal documento do convento de Colônia, que se conservava no arquivo da casa, veio a perder-se com

32 Esse ato de Filipe, o Belo, pode ser bem-avaliado, se tomarmos as referências de Dante a Bonifácio VIII. Como se sabe, Dante foi inimigo do papa, a quem julgava simoníaco, avarento e sem escrúpulos. Tanto é verdade que, na Divina Comédia (Inferno, c. XIX, 48-57), o coloca no inferno. Pois bem, o mesmo Dante ficou terrificado ante a prisão de Bonifácio em Anagni, por Nogaret, enviado de Filipe à Itália; devido a esse fato, colocou os seguintes versos na boca de Hugo Capeto, fundador da dinastia francesa, e que pelos crimes desta deverá ficar até ao fim dos tempos no purgatório: "Perchè men paia il mal futuro e il fatto, / veggio in Alagna intrar lo fiordaliso, / e nel vicario suo Cristo esser catto. / Veggiolo un'altra volta esser deriso; / veggio rinovellar l'aceto e "l fele, / e tra vivi ladroni esser anciso" ("E para que menor pareça o mal futuro e o destino, / vejo a flor-de-lis entrar em Anagni / e no seu vigário Cristo ser aprisionado. / Vejo-o ser novamente injuriado, / vejo renovar-se o vinagre e o fel, / e entre ladrões vivos ser alçado), Purgatório, c. XX, 85-90.

33 Essa hipótese foi aventada e defendida, com bons argumentos, por CALLEBAUT, A., 1928 (a e b). 
as leis de secularização e manumissão do século XIX. Em 1619, ele ainda foi compulsado pelo padre Mateus Ferkić, quando da transladação dos restos mortais de Scotus. Dizia o texto: "Rever(endo) P(adre) F(rei) João Duns Scotus, professor de Sagrada Teologia, conhecido como Doutor Sutil, outrora leitor em Colônia, que faleceu no ano de 1308, no dia 8 de novembro"34. Uns poucos dados, semelhantes aos dos demais frades falecidos, indicando, cristã e franciscanamente, a igualdade de todos perante Deus.

Os seus restos mortais encontram-se na Minoritenkirche (Igreja dos Frades Menores), em Colônia, bem próxima da catedral da mesma cidade.

\section{As obras}

A partir de fins do século XIX, iniciaram-se as edições críticas dos pensadores medievais. Quando se tratou de elencar, datar e editar-lhes as obras, nenhum deles apresentou tantas dificuldades como Duns Scotus. Isso se deveu a vários fatores.

Desde pouco após a sua morte, contava-se que, estando ele a caminhar com alunos em um prado, em Paris, foi-lhe entregue a ordem do Ministro-Geral que 0 transferia para Colônia. De imediato, anunciou aos acompanhantes que já estava partindo e, ao lhe perguntarem se não iria antes até ao convento, para se despedir, teria respondido: "O superior mandou-me ir para Colônia, não me mandou ir ao convento para despedir-me dos confrades". Lenda ou fato, o certo é que os seus escritos foram com ele para Colónia, onde continuou trabalhando na Ordinatio. Pouco depois, ele morria. Por decisão da Ordem, os escritos dos frades falecidos deveriam ser enviados ao convento de origem deles, isto, no caso de Scotus, para Oxford. Os discípulos defrontaram-se, então, com o legado do mestre na forma como fora deixado. Guilherme de Alnwick, seu último socius, foi quem mais se dedicou a salvar a obra do mestre e a editar-lhe os textos.

Ora, desde os seus últimos anos em Oxford, a partir de cerca de 1300, Scotus trabalhava na Ordinatio, isto é, no texto do comentário às Sentenças, que pretendia entregar aos livreiros para publicação, mas a obra ficara inconclusa. Desses comentários havia igualmente uma primeira redação, feita ainda em Oxford e utilizada para a aula, e as anotações dos ouvintes, seus auxiliares e alunos. Sabe-se também - e a edição crítica do primeiro livro da Ordinatio o mostra - que Scotus possuía uma espécie de fichário, ao qual remetia seguidamente, para que dele o secretário tomasse algum texto. Nada mais natural que Guilherme de Alnwick e/ou outros auxiliares tentassem, de algum modo, completar o que faltava na Ordinatio, valendo-se, para tanto, de outros textos do autor e também das próprias notas. E como não se salvaram os textos originais de Scotus, mas se multiplicaram às dezenas as cópias, com todo tipo de alterações, tornou-se complicado, mais tarde, separar a obra de Scotus dos rearranjos e das interpolações feitas por outros.

34 "Rever. P. F. Ioannes Scotus Sacrae Theologiae Professor, Doctor Subtilis nominatus, quondam lector Coloniae, qui obiit anno Domini 1308, sexto Idus Novembris" (ABATE, G., 1945, p. 34; ZAVALLONI, R., 1992, p. 25). 
O que se diz sobre a reconstituição dos comentários ao Livro das Sentenças aplicase também, a seu modo, às demais obras. Além disso, no decorrer do tempo, textos de outros autores passaram a ser atribuídos a ele e como tais foram editados. Assim, por exemplo, o Tractatus de modis significandi sive Grammatica speculativa - sobre o qual Heidegger haveria de fazer sua tese de Habilitação, em 1916 - é obra de Tomás de Erfurt; as Quaestiones disputatae de primo principio pertencem a Vital de Four, não propriamente como obra deste autor, mas como anotações particulares, baseadas, por vezes, em questões disputadas de Godofredo de Fontaines ${ }^{35}$; a Expositio in XII libros Metaphysicorum, a Antônio André; as Conclusiones utilissimae ex XII libris Metaphysicorum, a Gonçalo de Espanha. O mesmo se diga de alguns comentários à lógica de Aristóteles, quais sejam: In librum primum et secundum Priorum Analyticorum Aristotelis Quaestiones e In librum primum et secundum Posteriorum Analyticorum quaestiones, cuja autoria, crê-se, é de João de Cornuália. Também não são de Scotus as In libros Meteorologicorum Aristotelis quaestiones e a Dulcissima expositio et quaestiones in VIII libros Physicorum Aristotelis, que pertencem a Tomás de Bradwardine.

Somem-se a isso outros dois problemas. Em primeiro lugar, as inúmeras edições que foram feitas da obra - ou de partes da obra - de Scotus, desde o século XV. Entre 1472 e 1680, isto é, no período de 208 anos, contam-se 30 edições da Ordinatio, o que significa que a cada seis anos e meio foi impressa uma nova edição dessa obra ${ }^{36}$. Não é preciso dizer que os critérios dos editores de então eram bem diferentes dos de hoje: em muitos casos, fazia-se o trabalho valendo-se de um só ou de poucos manuscritos; suprimia-se o que se julgava estivesse errado ou fosse contrário à fé; acrescentava-se o que parecia conveniente para a melhor compreensão do texto ou para suprir lacunas. Isso não desqualifica de todo o trabalho de alguns editores, aos quais não se pode negar o esforço e a competência científica possível naquele tempo, que os deixam, porém, muito distantes das exigências da crítica moderna. É o caso, por exemplo, da edição preparada pelo irlandês Mauritius Hibernicus (O'Fihely), em 1506, e, mais ainda, aquela feita pelo também irlandês Lucas Wadding, em $1639^{37}$.

Apesar de tantas edições, e aqui surge o segundo problema, nem todas as obras mereceram a mesma atenção, e algumas jamais saíram dos manuscritos. 0 próprio Wadding anotava que, na edição que estava lançando, ativera-se tão-somente "aos temas especulativos", propondo-se a publicar, mais tarde, os trabalhos bíblicos, especificamente mencionados: Lectura in Genesim, Commentaria in Evangelia, Commentaria in epistolas S. Pauli, bem como os Sermones de Tempore e os Sermones de Sanctis $^{38}$.É de supor-se, logicamente, que Wadding, em seu tempo, ainda houvesse

35 Sobre a questão da não-autenticidade de obras atribuídas a Scotus, cf. VOS, A., 2006, p. 107-117.

36 Cf. Patres Editores. "De ordinatione I. Duns Scoti - Disquisitio historico-critica" (Vaticana I, p. $\left.127^{*}-139^{*}\right)$.

37 Dessa edição, em 12 volumes, foi feita uma reprografia (Hildesheim: Olms Verlag, 1968). Ela foi também reeditada em 26 volumes, noutro formato e com alguns acréscimos de textos (Paris: L. Vivès, 1891-1895). Dados sobre o número de manuscritos e o que já foi publicado pela edição crítica são encontrados, a seguir, ao serem elencadas as obras.

38 Cf. BALIĆ, C., 1965, p. 18. 
conhecido manuscritos dessas obras. Três séculos depois, a comissão, que preparou a edição crítica, e que para tanto vasculhou todas as bibliotecas da Europa, nada encontrou e sequer um manuscrito de algum desses textos bíblicos foi posteriormente descoberto. É sabido que tais manuscritos existiram em Oxford, pois Richard Layton, ao escrever a Oliver Cromwell, em 1535, referindo-se à ordem que recebera de destruir a obra de Scotus, dizia a seu chefe que, entre os livros que "banira para sempre de Oxford", encontravam-se também "as glosas cegas dele" ${ }^{39}$, isto é, os comentários aos textos bíblicos. Aliás, Cromwell determinara que a Sagrada Escritura fosse explicada literalmente, e não segundo Duns Scotus ${ }^{40}$, o que indica a importância que se concedia aos comentários bíblicos scotistas. Outra onda de destruição viria em 1550. Já naquele tempo as ditaduras costumavam queimar livros!

Para proceder à edição crítica da obra de Duns Scotus, a Commissio Scotistica, criada pela Ordem Franciscana, em 1938, e presidida por Carlos Balić, prosseguindo com os trabalhos preparatórios já antes iniciados, fez o levantamento e a análise dos manuscritos e das edições existentes. Nesse empreendimento, o método histórico-crítico e o uso de cálculos matemáticos revelaram-se de suma importância. No ano santo de 1950, foram lançados os dois primeiros volumes da Opera omnia. Até hoje, foram editados os volumes I-X, compreendendo os três primeiros livros da Ordinatio, e os volumes XVI-XXI, atinentes a tudo o que se possui da Lectura, isto é, até o livro III, pois não existe, ou ainda não se encontrou a Lectura IV. Essa edição é conhecida como Vaticana.

Entre 1997 e 2006, os frades franciscanos da Universidade Saint Bonaventure, nos Estados Unidos, valendo-se dos levantamentos feitos pela Commissio Scotistica, editaram as obras filosóficas de Scotus, isto é, os comentários a livros de Aristóteles e à Isagoge de Porfírio. Foram, ao todo, cinco volumes ${ }^{41}$.

Baseando-se principalmente na edição Wadding/Vivès, devidamente expurgada dos textos espúrios, G. Lauriola providenciou uma edição de toda a obra de Scotus, (Ioannis Duns Scoti - Opera omnia, Editio Minor, Alberobello: AGA Arti, 1998-2003). Importante nesse trabalho o Index scotisticus que a acompanha.

Os estudos introdutórios a cada volume da edição crítica são de fundamental importância para o conhecimento da vida e do pensamento de Scotus. Por eles, atribuem-se hoje a Scotus as obras listadas a seguir.

\section{A. Comentários a textos filosóficos ${ }^{42}$ :}

(i) Quaestiones in librum Porphyrii Isagoge (St. Bonaventure I, p. 1-245), 23 manuscritos. Não há dúvida de que essa obra, e as demais obras lógicas que se

39 WOLTER, A. B., 1993, p. 34; 1995, p. 191-192.

40 Cf. SHEPPARD, J. A., 2002, p. 291.

41 Nas indicações anteriores, e nas que se seguem, assim citamos as obras de Scotus: Vaticana (edição crítica, 1950s., indicando o volume e a página); St. Bonaventure (edição da Opera Philosophica, 1997s., também indicando o volume e a página); Vivès (reedição de Wadding, Paris, 1891-1895). Outras edições serão devidamente assinaladas no local onde forem mencionadas.

42 Além dos textos a seguir mencionados, foram descobertos, recentemente, um comentário à Metafísica e um aos Tópicos (cf. PINI, G., 1996 e 1999). 
seguem, são da autoria de Scotus. Não foi possível precisar a data de composição delas, mas tudo leva a crer que pertencem aos seus primeiros escritos, havendo alguns acréscimos posteriores.

(ii) Quaestiones super Praedicamenta Aristotelis (St. Bonaventure I, p. 247-645), 14 manuscritos.

(iii) Quaestiones in primum librum Perihermeneias Aristotelis (St. Bonaventure II, p. 9-132) e Quaestiones in duos libros Perihermeneias Aristotelis (ibid., p. 135-254), 13 manuscritos.

(iv) Quaestiones super librum Elenchorum Aristotelis (St. Bonaventure II, p. 255566), 2 manuscritos.

(v ) Quaestiones super libros Metaphysicorum Aristotelis (St. Bonaventure III-IV), 18 manuscritos. Pertencem a Scotus apenas os comentários aos Livros I-IX, sendo que outrem, após a morte do Doutor Sutil, redigiu o comentário aos Livros X-XII. Os editores observam que essa obra foi transmitida de forma caótica pelos diversos manuscritos, devendo-se isso, em parte, ao fato de Scotus haver corrigido e alterado o texto durante toda a vida ${ }^{43}$. Eles também confirmam (a) a opinião recente de que, ao contrário do que se supunha, Scotus trabalhou o texto durante toda a vida e (b) que as questões sobre os Livros VII-IX são obra da maturidade, e não dos primeiros anos de atividades acadêmicas ${ }^{44}$.

(vi) Quaestiones super secundum et tertium De anima (St. Bonaventure V, lançado em 2006 e concluindo a edição da Opera Philosophica), 25 manuscritos. A autenticidade da obra foi colocada em dúvida, devido ao fato de diversos manuscritos apresentarem Antônio André [Scotulus] como autor ${ }^{45}$. A maioria dos especialistas, nos últimos tempos, considera-a como autêntica e como pertencente aos primeiros anos de vida acadêmica de Scotus. Neste sentido se pronunciaram também os fautores autores da edição critíca ${ }^{46}$.

\section{B. Lectura, Ordinatio, Reportatio:}

Convém, de início, dar uma explicação sobre o que são propriamente os Comentários às Sentenças. Todo aluno que desejava estudar teologia precisava, antes, freqüentar a Faculdade de Artes (que nós, hoje, chamaríamos de Faculdade de Filosofia), onde, inicialmente, ensinavam-se as disciplinas do trivium e do quadrivium, mas onde, aos poucos, sempre mais foi sendo introduzida a obra de Aristóteles. Era natural que os jovens, ao ingressarem no curso de teologia, e tendo que se dedicar ao estudo da Sagrada Escritura, se sentissem perdidos e desapontados, por não terem à mão um texto sistemático, à semelhança das obras de Aristóteles. Foi o franciscano Alexandre de Hales quem por primeiro, na década de 1220, procurou sanar essa lacuna e, para tanto, resolveu utilizar como manual de estudos a obra de Pedro Lombardo (1095-1160), intitulada Quatro Livros das Sentenças.

43 St. Bonaventure III, p. XXXIII-XXXVIII.

44 Ibid., p. XLII-XLVI. Cf. DUMONT, S., 1995, p. 193-227; NOONE, T. B., 1995, p. 391-406.

45 Cf. Vaticana I, p. 152*.

46 Cf. INGHAM, M. B., 2003, p. 33; NOONE, TH., 2004, p. 270-271 
Pedro Lombardo, que fora professor da escola capitular em Paris e, depois, bispo da mesma cidade, distribuiu o texto em quatro livros, os quais, mais tarde, foram subdivididos em distinções, sendo esta a forma pela qual ficou conhecido: Livro I, Introdução (d. 1), a Trindade (d. 2-34) e os principais atributos divinos (d. 35-48); Livro II, a criação (d. 1-20) e o pecado (d. 21-44); Livro III, a encarnação (d. 1-22) e a vida da graça (d. 23-40); Livro IV, os sacramentos (d. 1-42) e a escatologia (d. 43-50). Não se trata de um texto original e nem possui grande estatura científica. Constitui-se, em grande parte, da compilação de textos, principalmente de Agostinho, mas também de outros Padres da Igreja e de contemporâneos, além, é claro, de conter inúmeras referências à Sagrada Escritura. Sistemático e de fácil compreensão, respondia à necessidade de um manual para o estudo de teologia.

Essas qualidades chamaram a atenção de Alexandre de Hales e, pouco depois, a experiência dele foi transformada em lei na Universidade de Paris e, no decorrer dos tempos, nas demais universidades. Todo bacharel, para ser promovido, era obrigado a fazer o Commentarium in quatuor libros Sententiarum (Comentário aos quatro Livros das Sentenças). Tratava-se, pois, de um trabalho de início da carreira acadêmica. Nas bibliotecas da Europa, há manuscritos de quase dois mil teólogos, que redigiram tais comentários ${ }^{47}$. Um deles, a propósito, foi um monge agostiniano chamado Martinho Lutero ${ }^{48}$. Nas primeiras décadas, os comentários faziam jus ao nome, seguindo à letra o texto de Pedro Lombardo. Entre eles, cabe citar, pela clareza e pelo equilíbrio, os de Boaventura e de Tomás de Aquino, que, anos depois, segundo o costume, os retocaram antes de entregá-los aos livreiros. Alguns, porém, deixando de lado uma reelaboração mais aprofundada, preferiram substituí-la por outra obra, como foi o caso de Tomás de Aquino, que os preteriu em favor da Suma teológica. Outros, a partir do fim do século XIII, deixando de lado a literalidade, serviram-se das distinções dos Quatro Livros das Sentenças para escrever longos tratados, nos quais o nome e o texto de Pedro Lombardo pouco significavam. Assim procederam, por exemplo, João Duns Scotus e Guilherme de Ockham.

Os comentários feitos por Scotus ao Livro das Sentenças chegaram a nós de três formas: como Lectura, como Ordinatio e como Reportatio ("leitura", "ordenação" e "reportagem" poderiam ser os termos da tradução para o português). Coube a C. Balić explicar o significado técnico de tais palavras. A Lectura era o texto elaborado pelo bacharel para apresentar em aula - seria algo como um rascunho ou uma primeira redação; a Ordinatio, o texto que o professor preparava para entregar aos livreiros, a fim de serem feitas cópias, isto é, tratava-se da obra definitiva do autor; já a Reportatio compunha-se das notas de aula, tomadas pelos alunos ou assistentes ${ }^{49}$.

Foi dominante até pouco tempo a afirmação de que Scotus teria comentado diversas vezes as Sentenças, e não apenas duas vezes, como se supunha no passado. Dizia-se que teriam sido quatro vezes: uma vez em Oxford, uma vez em Cambridge e

\footnotetext{
47 Apesar disso, muitos comentários devem ter-se perdido. Entre eles contam-se alguns de nomes famosos, como os de Henrique de Gand e de Godofredo de Fontaines.

48 Cf. VIGNAUX, P., 1935.

49 BALIĆ, C., 1965, p. 18-23.
} 
duas vezes em Paris. Do comentário feito em Oxford surgiu a Lectura. Mas, como se viu, já em Oxford, pouco antes de ser enviado a Paris, no início do século XIV, ele iniciou a redação da Ordinatio, valendo-se, para tanto, do texto da Lectura. Esse trabalho prosseguiu em Paris, servindo-se o autor também de anotações dos auxiliares (Reportationes) para compô-lo. Contudo, a Ordinatio nem sempre representa 0 pensamento definitivo do Doutor Sutil, a quem o tempo recusou tanto a possibilidade de completá-la, como a de fazer uma revisão final.

O levantamento exaustivo dos manuscritos, feito pela Comissio Scotistica, mostrou que existia a respeito dessas obras ${ }^{50}$ :

(I) Comentários ao Primeiro Livro das Sentenças

(i) Ordinatio I (Vaticana I-VI), 103 manuscritos.

(ii) Lectura I (Vaticana XVI-XVIII), 3 manuscritos.

(iii) Reportatio I-A (ed. Wolter ${ }^{51}$ ), 5 manuscritos. Esse texto é considerado de fundamental importância, tendo-se como certo que nele se encontra 0 pensamento definitivo de Scotus. Até pouco tempo merecia destaque o manuscrito de Viena (V), porque no explicit diz que foi revisado pelo próprio Scotus (daí chamar-se Reportatio examinata). Estudos recentes mostram que esse manuscrito possui interpolações e falhas e que, portanto, no estado atual, não provém diretamente de Scotus ${ }^{52}$.

(iv) Reportatio I-B (editada em Paris, em 1517), 1 manuscrito.

(v) Reportatio I-C (inédita), 1 manuscrito. Supõe-se, embora não unanimemente, que contém o comentário feito em Cambridge.

(vi) Reportatio I-D (inédita), 1 manuscrito.

(vii) Reportatio I-E (inédita), 1 manuscrito.

(II) Comentários ao Segundo Livro das Sentenças

(i) Ordinatio II (Vaticana VII-VIII), 74 manuscritos ${ }^{53}$. A edição crítica mostrou que as questões 15-25, entre outras, não chegaram a ser redigidas por Scotus, em sua forma definitiva.

(ii) Lectura II (Vaticana XVIII-XIX), 3 manuscritos.

(iii) Reportatio II (Vivès XXII, p. 513 - XXIII, p. 233), 7 manuscritos.

50 O número de manuscritos é tomado do levantamento feito quando da preparação da edição crítica (cf. Patres Editores. "Disquisitio historico-critica", Vaticana I, p. 144*-155*).

51 WOLTER, A. B. and BYCHKOV, O. (ed.), John Duns Scotus - The Examined Report of the Paris Lectures Reportatio I-A (Latin and English Texts), St. Bonaventure: Franciscan Institute, vol. I, 2004; vol II, 2007.

52 Mesmo WOLTER, A. e BYCHKOV, O. (2004, p. XIX-XXIV), que editaram a Reportatio examinata, partiram do princípio que era necessário tomar em consideração os cinco manuscritos e, à luz deles, partir para um diálogo com o autor, no modelo proposto por H. G. Gadamer. Mais radical ainda é a posição de SÖDER, J. R. (2005, p. 30-32), ao editar e traduzir as questões 38-44, do Livro I. Como o próprio Söder diz, a longa convivência com esses manuscritos, que lhe proporcionara já a edição de textos em 1998, permitiulhe concluir que o manuscrito $\mathrm{M}$, de Oxford, que provém de uma antiga tradição, é muito mais confiável. Isso o levou a editar esse texto, e não o manuscrito V, de Viena, que serviu apenas para ser comparado com M. A respeito da posição de RÖDLER, K., cf. n. 57, abaixo.

53 Vaticana VIII, p. 1*-76*. A respeito das interpolações nesse livro, principalmente das questões 15-25, cf. ibid., p.79*-93*. 
(III) Comentários ao Terceiro Livro das Sentenças

(i) Ordinatio III (Vaticana IX-X), 57 manuscritos.

(ii) Lectura III (Vaticana XX-XXI, e aqui se encerra o que se possui hoje da Lectura), 3 manuscritos.

(iii) Reportatio III-A (Vivès XXIII, p. 234-530), 4 manuscritos.

(iv) Reportatio III- $B$ (inédita), 1 manuscrito.

(v) Reportatio III-C (inédita), 2 manuscritos.

(vi) Reportatio III-D (inédita), 1 manuscrito.

(IV) Comentários ao Quarto Livro das Sentenças

(i) Ordinatio IV (Vivès XVI-XXI), 78 manuscritos.

(ii) Reportatio IV-A (Vivès XXIII, p. 531-XXIV), 5 manuscritos.

(iii) Reportatio IV-B (editada em Paris, 1518), 4 manuscritos.

Como foi dito acima, não existe a Lectura deste Livro.

\section{Additiones magnae:}

Como se verá, trata-se, em si, de uma obra espúria. Entretanto, pelo modo de sua composição e pelo que ela significou durante séculos, a colocamos aqui. Vivès XXII, p. 1-512, publicou a primeira parte [in I Sententiarum], da qual há 12 manuscritos; a segunda parte [in II Sententiarum], com 8 manuscritos, permanece inédita. Trata-se de uma adenda aos Livros I e II da Ordinatio. Guilherme de Alnwick, secretário e colega de Scotus, foi quem compilou essa obra, entre 1312 e 1325. C. Balić era da opinião de que ela provinha das notas de aula tomadas por Alnwick, tendo, pois, o caráter de uma Reportatio ${ }^{54}$. Essa opinião foi questionada, o que levou os editores a um estudo mais detalhado, que veio a rever, em parte, o que fora anteriormente afirmado ${ }^{55}$. A intenção de Alnwick era evidente: completar a Ordinatio, que o falecimento prematuro de Scotus deixara incompleta, sendo que muitas questões tratadas em Paris, e mesmo em Oxford, nela não se encontravam ou mal tinham sido aventadas. Para a Ordinatio I, Alnwick se valeu da Reportatio I-A, da qual extraiu 47 questões, com pequenas abreviações ou deixando de lado pequenos textos. Já para o segundo Livro, ele foi além: valeu-se da Reportatio II-B, e por vezes da II-A, mantendo fidelidade ao texto em $80 \%$ dos casos; quando, porém, em $20 \%$ dos casos, apelou para a Lectura II, a fim de completar o que faltava nas Reportationes, agiu com muito maior liberdade, resumindo, acrescentando, dando exemplos próprios, fazendo considerações que não provinham de Scotus.

Se, pois, por vezes, Alnwick foi além de Scotus, até mesmo colocando textos que o mestre anotara expressamente que não deveriam ser utilizados na Ordinatio, não quis, contudo, compor uma obra própria, o que se comprova por utilizar o nome de Scotus em primeira pessoa e por não haver inserido o próprio texto no corpo da Ordinatio. Essa intenção se manifesta também nos copistas, como naquele do manuscrito Vaticano (lat. 876), que anotou no final: "Concluem-se as Adições do

54 Cf. BALIĆ, C., 1927, p. 9.

55 Cf. Vaticana VIII, p. 76*-93*. 
segundo livro do mestre João de Duns, Doutor Sutil, extraídas pelo mestre Guilherme de Alnwick, da Ordem dos Frades Menores, da leitura de Paris e de Oxford do predito mestre João" 56 . Infelizmente, porém, os pósteros, na ânsia de terem a Ordinatio como obra completa, incluíram nela as Additiones e permitiram-se acréscimos e cortes, além de tomarem perícopes de outros teólogos, o que dificultou enormemente 0 trabalho crítico dos editores, maximamente no que se refere à Ordinatio II ${ }^{57}$.

56 "Expliciunt Additiones secundi libri magistri Ioannis de Duns, Subtilis Doctor, extractae per magistrum Wilhelmum de Alnwick, de Ordine Fratrum Minorum, de lectura Parisiensi et Oxoniensi praedicti magistri Ioannis" (Vaticana VIII, p. 78*).

57 O que aqui é dito a respeito dos Comentários às Sentenças feitos por Scotus representa o pensamento da Commissio Scotistica e tem sofrido restrições por parte de inúmeros autores. A respeito das diversas formas de Comentários às Sentenças feitos por Scotus, especificamente das Reportata, tem um aspecto quase revolucionário o livro de RODLER, K. Die Prologe der Reportata Parisiensia des Johannes Duns Scotus. Untersuchung zur Textüberlieferung und kritische Edition. Não porque contenha algo totalmente novo, pois retoma seu trabalho de doutorado, mas porque parece aclarar definitivamente algumas questões.

A obra se coloca na linha dos trabalhos encetados por RICHTER, W. (1988) e LIEBHOLD, G. (1998). Para situar esses textos, convém observar que o elenco e a datação da obra de Scotus, hoje aceitos, em linhas gerais, como doctrina communis por quase todos os pesquisadores, provêm principalmente dos estudos de BALIĆ, C., iniciados já com Les commentaires de Jean Duns Scot sur les quatre livres des sentences, e prosseguidos com a "Disquisitio historico-critica", que inicia o volume I da Opera omnia de Scotus e, posteriormente, no artigo "The Life and Works of John Duns Scotus". Balić apresentou, no elenco de obras de Scotus, diversas Reportationes (notas de aula de assistentes e de ouvintes), referentes a diferentes cursos ministrados sobre As Sentenças de Pedro Lombardo. RICHTER, W. (op. cit. p. 12) qualificou de "quase sensacional" o aumento quantitativo que as obras do franciscano escocês tiveram com as descobertas do frade croata. Além disso, ele, W. Richter, juntamente com G. Liebhold, mantiveram uma distância crítica ante a Comissão que cuidou da Opera Omnia de Scotus, por julgarem que ela ficou mais distante do original do Doutor Sutil do que supunha.

$\mathrm{K}$. Rodler, em sua obra, segue pelos caminhos traçados por seus antecessores de Innsbruck, tomando como tema para seu estudo os prólogos das Reportationes I-A, I-B e I-C. e das Additiones Magnae. (As Reportationes I-D e I-E não são levadas em consideração porque os próprios editores da Opera omnia modificaram a opinião e consideram que I-D representa a mesma redação de I-C; e I-E, no que tem de específico, é transcrição de questões redigidas por Henrique de Harclay [p. 35s]). 0 autor coteja esses textos entre si e mostra que eles possuem tanta semelhança uns com os outros que se pode concluir pela proveniência deles de uma mesma fonte. "Se na edição do texto - diz ele -, eles fossem colocados lado a lado, em longas passagens, como por exemplo, no artigo 3, a gente teria dificuldade de distinguir entre si as Reportationes 1-A, 1-C e as Additiones Magnae" (p. 41). Também, comparando os diversos manuscritos de cada obra e o conjunto de todos eles, constata que textos complementares, supressões, ou o mesmo texto em diferente ordem ou texto objetivamente igual em formulação diferente são comuns a muitos manuscritos (p. 41-42)

Portanto, ao contrário do que se pensou até a pouco tempo, elas não seriam fruto de cursos diferentes ministrados por Scotus, mas reproduziriam todas, a seu modo, anotações, feitas por assistentes e ouvintes, de aulas dele em Paris, na única vez que teria comentado as Sentenças nessa cidade.

Contudo, as complicações não se acabam por aí. K. Rodler também constata que a influência entre Reportatio I-A e Additiones Magnae é recíproca. Ora, é aceito por todos que as Additiones provêm da pena de Guilherme de Alnwick e foram compostas alguns anos após a morte de Scotus. Se, pois, elas se fazem presentes em partes do texto da Reportatio I-A, isto significa que os manuscritos desta, hoje existentes, não são cópia fiel do original, composto por um ouvinte, a partir das aulas de Scotus e durante a vida deste. Acontece, porém, que o manuscrito Viena 1453 tem em seu explicit a afirmação de que se trata de uma reportatio 'examinata cum eodem venerando doctore'. Isso levou os autores a considerar a Reportatio I-A como sendo a mais importante de todas e a portadora do pensamento definitivo de Scotus. $\mathrm{K}$. Rodler não nega que ela seja a mais importante, e mesmo que possa retratar as últimas formulações 


\section{Quaestiones quodlibetales:}

Vivès XXV-XXVI e Alluntis $1963^{58}$, entre outros, publicaram o texto. Falta, para o mesmo, uma edição crítica. Há 67 manuscritos. Como o nome indica, Questão quodlibetal significa "questão sobre qualquer tema" 59 . Ela surgiu em Paris e foi adotada progressivamente pelas demais universidades. "Determinar" tal questão

do pensamento do grande mestre, mas relativiza a afirmação de que foi examinada por Duns Scotus (p. 53-63 e 114-126). Para tanto, mostra que no Prólogo ela possui longas e longas passagens tomadas das Additiones, ou substitui trechos daquela por trechos desta, ou mistura ambas. Isso comprova que "o texto do Prólogo de Viena 1453 é o resultado de uma comparação sistemática entre a Reportatio I-A com as Additiones Magnae" (p. 62). É possível que o texto original dela tenha sido examinado por Scotus, mas disso não há nenhum testemunho. E possível que tal original tenha sido revisto por ele em suas grandes linhas, mas seguramente não nas minúcias, pois há tópicos que não se coadunam com o pensamento dele. Enfim, cabe recordar que só o manuscrito Viena 1453 possui tal explicit, exatamente ele, o que o mais se vale das Additiones.

Uma última questão à qual convém chamar a atenção é a afirmação, defendida pela Comissio Scotistica, de que a Reportatio I-C é fruto da atividade acadêmica de Scotus em Cambridge. Os argumentos a favor desta opinião baseiam-se em um texto do manuscrito Merton 66, que diz: Haec de Ordinatione venerabilis fratris Joannis Duns, de Ordine Fratrum Minorum, qui floruit Cant[abrigiae], Oxon[ii] et Parisius et obiit in Colon[ia]. Em outro texto, confirmado por quatro manuscritos, lê-se: Habetur in q. cant.[...] Alia quaestio [..] cuius illa cant. potest esse articulus (Ord. I, d. 4, p. 1, q. un.;-Vat. IV, 1. Na introdução a este volume, p. $1^{*}-46^{*}$, os editores oferecem sua interpretação a esse texto). À luz desses tópicos concluiu-se: Floruit Cant. significa que Scotus lecionou em Cambridge; q. cant. (que se resolveria em quaestio cantabrigensis) está remetendo o leitor para o texto que elaborou naquela universidade. K. Rodler discorda dessa interpretação (p. 92-111), observando que, na lista dos franciscanos que lecionaram em Cambridge, não se encontra o nome de Scotus. Ele poderia ter estado nessa cidade durante o estágio previsto pela Ordem, ou poderia ter sido estudante e não professor, mas não possuímos documentos que confirmem tais hipóteses. Além disso, prossegue K. Rodler, não é muito fácil encontrar uma data em que ele possa ter lecionado em Cambridge e constata-se que aqueles que se houveram com esse problema indicam as mais diferentes datas. Por outro lado, can ou cant poderia ser resolvida como cancelarii (chanceler), e estaria remetendo a Henrique de Harclay, que escreveu após a morte de Scotus e de quem foram tomadas algumas questões nas Reportationes. Comparando o manuscrito Todi 12, que traz o texto em questão, com os das demais reportationes, constata-se que ele também incorpora partes das Additiones Magnae e não difere fundamentalmente dos outros, o que o coloca como uma Reportatio parisiensis, tal como os demais. Que se pode dizer disso tudo? Em primeiro lugar, comprova-se como é difícil lidar com as reportationes, algo que já fora observado por HAMESSE, J. (1986).

Mais do que isso, porém, é preciso dizer que a obra do Prof. K. Rodler é um desaguadouro de inúmeros trabalhos de especialistas que discordam, em alguns tópicos, da leitura feita pelos editores da obra de Scotus e pela maioria dos scotistas da atualidade. Nesse volume, pela primeira vez, são editados juntos e cotejados os prólogos das três Reportationes I e das Additiones Magnae e é a partir desses textos que o autor argumenta. Sem dúvida, muitas questões ficam em aberto e de muitas propostas se haverá de discutir. Creio, contudo, que algumas teses fundamentais haverão de se impor, e cito três delas: 1) a de que os manuscritos de que dispomos mostram que há uma interpenetração entre as reportationes e as Additiones Magnae (o que está a indicar que não dispomos, no caso, de nenhum texto que provenha diretamente de Scotus) e, conseqüentemente, 2) que aquilo que se diz, comumente, da Reportatio examinata deve ser revisto, 3) como também deve ser revisto o que se afirma da Reportatio cantabrigensis. Quanto a esse último ponto, porém, parece-nos, contudo, que, divergindo de K. Rodler, o estudo de Vos (2006; cf. acima, n. 21), consegue determinar devidamente a data desta Reportatio, e explicar o motivo porque Scotus não é citado na lista dos professores de Cambridge.

58 Cuestiones quodlibetales (Obras del Doctor Sutil Juan Duns Scotus). Edición bilingüe. Introducción, Resúmenes y versión de Felix Alluntis, O. F. M. Madrid: BAC, 1968.

59 Os melhores textos sobre o tema são os de GLORIEUX, P. Entre outros: La littérature quodlibétique, de 1260 à 1360. Paris: Vrin, 1924; La littérature quodlibétique. Paris: Vrin, 1935. Na literatura recente, cf. BAZÁN, B. C. et alii, 1985. 
era direito que assistia somente aos professores, embora nem todos tenham tido a coragem suficiente para expor-se a um debate de tal magnitude. Outros, como Godofredo de Fontaines e Henrique de Gand, nos longos anos de magistério, por 15 vezes as promoveram; Tomás de Aquino, por 12 vezes. 0 período reservado para tanto era o advento ou a quaresma.

Ao contrário das "questões disputadas", que aconteciam diariamente e ficavam restritas aos alunos de cada mestre, a quem cabia determinar o tema a ser debatido, quando de uma questão quodlibetal as aulas eram suspensas e dava-se ciência a toda a cidade. Dependendo do professor e dos temas em foco no momento, acorriam o bispo, o legado papal, o clero, funcionários da corte, pessoas em trânsito e o pessoal docente e discente da universidade. $\mathrm{E}$ a todos era permitido formular perguntas e objeções a respeito de qualquer tema. $O$ mestre vinha acompanhado por seus bacharéis, prevendo os estatutos da universidade que ninguém fosse promovido a mestre sem antes haver tomado parte como bacharel em uma disputa quodlibetal. Cabia a eles auxiliar o mestre na articulação da resposta. Além disso, os bacharéis anotavam resumidamente o debate, na desordem como ia acontecendo. Valendo-se dessas anotações, o mestre, no decorrer do tempo, revia o texto e o preparava para entregá-lo aos livreiros da universidade. A maioria, ou melhor, a totalidade dos manuscritos e as edições que temos desses debates não reproduzem, portanto, o que aconteceu no dia em que se realizou o quodlibet, mas, sim, a reelaboração do que foi então discutido. Nessas questões, mais do que em qualquer outro texto, reflete-se não só o dia-a-dia da universidade, mas também o mundo socioeconômico e cultural de cada época.

Scotus determinou o seu quodlibet no advento de 1306 ou na quaresma de 1307. Dividiu-o em 21 questões. Em comparação com a Ordinatio, o texto é mais fluente. Foi, provavelmente, a sua última obra. Daí a importância a ela conferida, quando, a respeito de algum tema, se pergunta pelo pensamento definitivo dele.

\section{E. De primo principio:}

Edição crítica de Marianus Müller ${ }^{60}$. Há 15 manuscritos. Sem dúvida, o autor é Duns Scotus, que, porém, deve ter dado as indicações gerais a um seu auxiliar, e este, pelo que se constata, não era dos mais eficientes, pois omitiu ou acrescentou palavras e frases, tornando o texto, por vezes, de mui difícil compreensão. Trata-se da obra mais conhecida de Scotus, traduzida para inúmeras línguas ${ }^{61}$. Chama a atenção nesse tratado: (a) o fato de ser o primeiro livro escrito nos séculos XIII e XIV que é dedicado especificamente ao problema da existência de Deus e de seus atributos, algo feito anteriormente por santo Anselmo, no século 12; (b) a semelhança,

60 Ioannis Duns Scoti - Tractatus de primo principio. Primo recensuit et emendavit Marianus Muller O. F. M., Freiburg: Herder, 1941. O levantamento dos manuscritos e o cotejo entre eles podem-se tomar como definitivos, embora sempre sujeitos a pequenas correções. Mas, não houve interesse, por parte do autor - e naquele tempo talvez nem fosse possível -, em cotejar o texto com outras obras de Scotus, bem como em identificar fontes não citadas explicitamente.

61 Em língua portuguesa, existe já a tradução de M. Santiago de Carvalho: João Duns Escoto - Tratado do primeiro princípio. Lisboa: Edições 70, 1998. 
na distribuição do material, entre o Proslógio de Anselmo de Cantuária e o De primo principio $^{62}$; (c) o fato de cerca de $50 \%$ do texto ser reprodução verbal de três partes

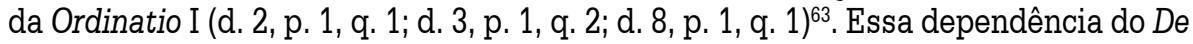
primo principio ante a Ordinatio indica, por um lado, que aquele é posterior a esta, 0 que confirma a tradição que colocava o tratado como uma das últimas obras de Scotus; por outro lado, porém, não se trata de uma simples reprodução do que já fora dito, pois o texto é reagrupado, há cortes e inserções, constitui-se numa unidade temática nova e há um progresso na argumentação do autor a respeito das provas da existência de Deus e dos atributos divinos.

\section{F. Theoremata:}

Edição crítica por St. Bonaventure II, p. 567-757. Há 4 manuscritos. Obra inconclusa e marcada por algumas aporias, esse pequeno tratado oferece enormes dificuldades, a começar pela da autoria. Muitos pesquisadores negaram que Scotus fosse o autor, pois há doutrinas que divergem radicalmente daquilo que foi ensinado por ele, em todas as demais obras, sobre a existência e alguns atributos de Deus. Os editores e a maioria dos pesquisadores mais recentes, baseados em fundamentos externos e internos, defendem, porém, que Scotus é, de fato, o autor, embora admitam que a disposição das diversas partes em um único texto não se deva atribuir a ele, como também a ele não se deve atribuir o nome dado à obra. Dizem esses especialistas que, nela, Scotus está sendo fiel ao que afirmou, em outros lugares, a respeito do modo de demonstração, que pode ser tanto por um argumento quia (a partir dos efeitos) como por um argumento propter quid (pela evidência da causa). Ora, nas demais obras, a argumentação de Scotus a respeito da existência de Deus foi sempre uma argumentação quia, como ele deixou bem claro. Nos Theoremata, porém, ele está tratando de provas propter quid, na perspectiva dos Segundos analíticos de Aristóteles, e, a essa luz, mostra então que não se pode provar a existência de Deus, através de uma argumentação categórico-dedutiva. Não sem razão, como observam os editores, uma nota marginal, em um dos manuscritos, diz tratar-se de "coisas que não se deixam provar demonstrativamente a respeito de Deus, por meio de argumentos meramente racionais, e enquanto ele é a causa de outros seres" ${ }^{64}$.

\section{G. Collationes:}

Estão ainda sem edição crítica ${ }^{65}$. Uma delas é inédita. Há 8 manuscritos. A palavra collatio ("colação") possui sentidos diversos na terminologia medieval. Em

62 Cf. PRENTICE, R., 1964, p. 77-109.

63 Cf. Vaticana I, p. $161 *-164^{*}$.

64 "Quae non possunt probari demonstrative de Deo ex naturalibus et ut est causa aliorum" (St. Bonaventure II, p. 580).

65 L. Wadding publicou 37 collationes (Cf. WADDING, L. Opera omnia, vol. 3, Lugduni, 1639, p. 339-430; reprint Hildesheim: HOLMS, G., 1968; Vivès V, 131-312). A edição recente, não-crítica, providenciada por G. Labriola, reproduz as anteriores. C. Harris publicou mais 5 colações. Existe uma que ainda se encontra inédita (cf. VOS, A., 2006 p. 134-136). 
santo Tomás, como observa P. Mandonnet, indica pequenos discursos ou conferências ${ }^{66}$. Em são Boaventura, são longas seqüências de sermões acadêmicos, do mais alto nível teológico. Em Duns Scotus, são pequenos tratados. São, ao todo, 43 collationes, 24 redigidas em Oxford, e 19 em Paris. Até hoje, essa obra foi pouco estudada, embora fosse de importância para Scotus, que a ela se referiu diversas vezes na revisão da Ordinatio ${ }^{67}$.

\section{H. Debates acadêmicos:}

Os editores da Opera omnia indicam manuscritos, nos quais se encontram textos das disputas que Scotus manteve com colegas. Seriam elas: com seu confrade frei Egídio de Ligny, por ocasião de sua promoção; com frei Filipe de Bridlington, nas Vésperas de promoção; com o dominicano Guilherme Pedro Godino, sobre o princípio de individuação ${ }^{68}$.

\section{Referências bibliográficas}

ABATE, G. M. "La tomba del ven. Giovanni Duns Scoto, O. M., nella chiesa di San Francesco a Colonia. Nota e documenti". Miscellanea Francescana, 45 (1945), p. 29-79.

AUBERT, R. "Jean Duns Scot [min. +1308]". Dictionnaire d'Histoire et de Géographie Ecclésiastiques t. XXVI. Paris, 1997, col. 1489-1491.

BALIĆ, C. Les commentaires de Jean Duns Scot sur les quatre livres des sentences. Louvain: Biblioteque de la Revue d'Histoire Ecclésiastique, 1927.

. "Disquisitio historico-critica", Johannis Duns Scoti Opera omnia. Roma: Vaticana, 1950. p. $1 *-330 *$

. "Henricus de Harcley et Ioannes Duns Scotus". Mélanges offerts à E. Gilson. Paris/ Toronto, 1954. p. 95-121.

. "The Life and Works of John Duns Scotus". In: RIAN, J. K.; BONANSEA, B. (org.). John Duns Scotus 1265-1308. Washington: The Catholic University of America, 1965. p. 1-27.

BAZÁN, B. C. et al. Les questions disputées et les questions quodlibétiques dans les facultés de théologie, de droit et de médecine. Turnhout: Brepols, 1985.

BAZAN, C.; EMERY, K.; GREEN, R.; NOONE, Th.; PLEVANO, R.; TRAVER, A. "Introduction". In: Beati Joannis Duns Scoti: Quaestiones super secundum et tertium De anima (OPh V). Washington/St. Bonaventure: CUA/ The Franciscan Institute, 2006. p. 121*-143*.

BRAMPTON, C. K. "Duns Scotus at Oxford 1288-1301". Franciscan Studies, 24 (1964), p. 5-20.

CALLEBAUT, A. "Le bx. Jean Duns Scot étudiant à Paris vers 1293-1296". AFH, 17 (1924), p. 3-12.

. Le bx. Jean Duns Scot: bachelier des Sentences à Paris en 1302-1303. La France Franciscaine, 9 (1926), p. 293-317.

. "La maîtrise du bx. Jean Duns Scot en 1305 et son départ de Paris en 1307 durant la préparation du procès contre les templiers". AFH, 21 (1928/a), p. 206-239.

66 Cf. Vaticana I, p. 151*; J. HAMESSE, 1988, p. 78-87.

67 Cf. DUMONT, S., 1996, p. 69; WILLIAMS, TH., 2003, p. 10.

68 Cf. Vaticana I, p. 150*. Os manuscritos apontados encontram-se, respectivamente, em Valência, Worcester e Erfurt. A disputa com Godino foi publicada por STROICK, C., 1974, p. 559-608. 
. "Encore sur la maîtrise du bx. Jean Duns Scot et son départ de Paris en 1307". AFH, $21(1928 / \mathrm{b})$, p. $418-419$.

. "Le bx. Jean Duns Scot à Cambridge vers 1297-1300". AFH, 21 (1928/c), p. 608-611.

"Le séjour du bx. Jean Duns Scot à Paris. Son milieu universitaire". La France Franciscaine, 12 (1929), p. 353-373.

. "A propos du bx. Jean Duns Scot de Littledean". AFH, 24 (1931), p. 305-329.

CHRONICA XXIV Generalium Ordinis Minorum (Analecta Franciscana III). Quaracchi, 1897.

COURTENAY, W. J. "Scotus at Paris". SILEO, L. (org.). Methodologica ad mentem Joannis Duns Scoti. Roma: Ed. Antonianum, vol. I, 1995. p. 149-163.

CROSS, R. Duns Scotus. Oxford/New York: OUP, 1999.

DENIFLE, H.; CHATELAIN, A. (ed.). Chartularium Universitatis Parisiensis. Paris: Delalain, 1889-1897.

DOCHERTY, H. “The Brocki Mss. and Duns Scotus”. The Innes Review, 16 (1965), p. 79-127.

. "The Brochi Forgeries". De doctrina Ioannis Duns Scoti - Acta Congressus Internationalis Oxonii et Edimburgi 11-17 september 1966. Roma: Commissio Scotistica, vol. I, p. 327-360.

DUMONT, S. D. "The Question on Individuation in Scotus's 'Quaestiones super Metaphysicam'”. SILEO, L. (org.). Methodologica ad mentem Joannis Duns Scoti. Roma: Ed. Antonianum, vol. I, 1995, p. 193-227.

. "William of Ware, Richard of Connington and the 'Collationes Oxonienses' of John Duns Scotus". HONNEFELDER, L.; WOOD, R.; DREYER, M. (eds.). John Duns Scotus: Metaphysics and Ethics. Leiden: Brill, 1996. p. 59-85.

HAMESSE, J. "Les problèmes posés par l'edition critique des reportations". Franciscan Studies, 46 (1986), p. 107-117.

. “'Collatio' et 'reportatio': deux vocables spécifiques de la vie intellectuelle au moyen âge". In: WEIJERS, O. (ed.). Terminologie de la vie intellectuelle au moyen age. Tournhout: Brepols, 1988, p. 78-87.

HECHICH, B. De immaculata conceptione beatae Mariae Virginis secundum Thomam de Sutton O. P. et Robertum de Cowton O. F.M. Roma, 1958.

INGHAM, M. B. Scotus for Dunces. An introduction to the Subtle Doctor. St. Bonaventure: Franciscan Institute, 2003.

KLIBANSKI, R. Commentarium de Eckardi magisterio (Opera latina XIII). Leipzig, 1936, p. XXX-XXXIII.

LIEBHOLD, G. "Zur Kontroverse zwischen den Philosophen und Theologen in der ersten Quaestio des Prologs der 'Ordinatio' des Johannes Duns Scotus". Was ist Philosophie im Mittelalter (Miscellanea Mediaevalia, 26 [1998], Berlin: De Gruyter, p. 629-636).

LITTLE, A. G. "Chronical notes on the life of Duns Scotus". English Historical Review, 47 (1932), p. 568-582.

. "Letter of Bonagratia, Minister General, to Edward I, King of England, A. D. 1282, with some Notes on Visitations of Provinces by Ministers General in the $13^{\text {th }}$ Century". AFH, 26 (1933), p. 236-241.

. "Two Sermons of Fr. Raymundi Gaufredi, Minister General, preached at Oxford in 1291". Collectanea Franciscana, 4 (1934), p. 161-174. 
LITTLE, A. G. Franciscan papers, lists and documents. Manchester: MUP, 1943.

LONGPRÉ, E. "Le bx. Jean Duns Scot: Pour la Sainte Siège et contre le gallicanisme (25-28 juin 1303)". La France Franciscaine, 11 (1928), p. 137-162.

. "L'ordination sacerdotale du bx. Jean Duns Scot: document du 17 mars 1291". AFH,

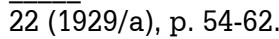

. "Phillipe de Bridlington e le bx. Duns Scot". AFH, 22 (1929/b), p. 587-588.

. "Nouveaux documents franciscains d'Escosse". AFH, 22 (1929/c), p. 588-589.

NOONE, T. B. "Scotus's critique of the Thomistic theory of individuation and the dating of the 'Quaestiones in libros Metaphysicorum' VII, q. 13". L. Sileo (org.). Methodologica ad mentem Joannis Duns Scoti. Roma: Ed. Antonianum, vol. I, 1995, p. 391-406.

. "L'univocité dans les 'Quaestiones super libros de anima'”. Boulnois, O. et al. (org.).

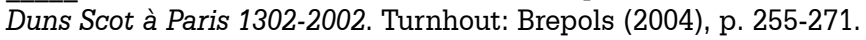

PELSTER, F. "Handschriftliches zu Scotus mit neuen Angaben über sein Leben". Franziskanische Studien, 10 (1923), p. 1-32.

PELZER, A. "Le premier livre des Reportata Parisiensia de Jean Duns Scot". Annales de l'Institut Supérieur de Philosophie, 5 (1924), p. 447-492.

PINI, G. “'Notabilia Scoti super Metaphysicam': Una testimonianza ritrovata dall' insegnamento di Duns Scoto sulla 'Metafisica'”. AFH, 89 (1996), p. 137-180.

. "Duns Scotus' Commentary on the Topics: new light in his philosophical teaching". $\overline{A H D L} M A, 66$ (1999), p. 225-243.

PRENTICE, R. "The 'De primo principio' of John Duns Scotus as a Thirteenth Century 'Proslogion'”. Antonianum, 39 (1964), p. 77-109.

RICHTER, W. Studien zum litterarischen Werk von Johannes Duns Scotus. München: Bayerische Akademie der Wissenschaften, 1988.

ROBSON, M. “The Birth-Place of Blessed John Duns Scotus. Thomas Gascoigne a Hitherto Unnoticed Witness". Miscellanea Francescana, 103 (2003), p. 703-718.

RODLER, K. Die Prologe der Reportata Parisiensia des Johannes Duns Scotus. Untersuchung zur Textüberlieferung und kritische Edition. Innsbruck: Universitätsverlag, 2005.

SAINT-MAURICE, B. João Duns Scot, doutor dos tempos novos. (Trad. Luis L. Ferreira). Petrópolis: Vozes, 1947.

SHEPPARD, J. A. "Vita Scoti". Franciscan Studies, 60 (2002), p. 291-323.

SÖDER, J. R. Johannes Duns Scotus - Pariser Vorlesung über Wissen und Kontingenz. Freiburg: Herder, 2005, p. 9-32.

SONDAG, G. Duns Scot: la théologie comme science pratique. Paris: Vrin, 1996, p. 7-23.

STROICK, C., "Eine Pariser Disputation vom Jahre 1306. Die Verteidigung des thomistischen Individuationsprinzips gegen Johannes Duns Scotus durch Guillelmus Petri de Godino O. P.". In: ECKERT, W. P. (ed.). Thomas von Aquino: Interpretation und Rezeption. Mainz: Grünewald, 1974, p. 559-608.

VIGNAUX, P. Luther: Commentateur des Sentences. Paris: Vrin, 1935.

VOS, Antonie. "Duns Scotus at Paris". Boulnois, O. et alii (org.). Duns Scot à Paris 13022002. Turnhout: Brepols (2004), p. 3-19.

. The Philosophy of John Duns Scotus. Edinburgh: Edinburgh University Press, 2006. 
WILLIAMS, Thomas. "The life and the works of John Duns the Scot". Id. (ed.). The Cambridge Companion to Duns Scotus. Cambridge: CUP, 2003. p. 1-14.

WILSON, G. A. "The presence of Henry of Ghent in Scotus's 'Quaestiones super libros metaphysicorum'". HONNEFELDER, L.; WOOD, R.; DREYER, M. (eds.). John Duns Scotus: Metaphysics and Ethics. Leiden: Brill, 1996. p. 107-124.

WOLTER, A. B. "Reflections on the life and works of Scotus". American Catholic Philosophical Quarterly, 57 (1993), p. 1-36.

. "Duns Scotus at Oxford". SILEO, L. (org.). Methodologica ad mentem Joannis Duns Scoti. Roma: Ed. Antonianum, vol. I, 1995, p. 183-192.

. "Reflections about Scotus early works". HONNEFELDER, L.; WOOD, R.; DREYER, M. (eds.). John Duns Scotus: Metaphysics and Ethics. Leiden: Brill, 1996. p. 37-57.

ZAVALLONI, R. Giovanni Duns Scoto - Maestro di vita e pensiero. Bologna: Ed. Francescane, 1992. 